\title{
Analysis of Dangerous Conditions and Actions of the Painting Process
}

Tri Ngudi Wiyatno ${ }^{1}$, Fibi Eko Putra ${ }^{1 *}$, Muhammad Aldi Albana ${ }^{1}$, Tri Handoyo ${ }^{1}$, Muhammad Rizki Oktavian ${ }^{1}$, Putri Nika Andini Hidayat ${ }^{2}$

${ }^{1}$ Department of Industrial Engineering, Pelita Bangsa University, Bekasi 17530, Indonesia

${ }^{2}$ Department of Environmental Engineering, Pelita Bangsa University, Bekasi 17530, Indonesia

Corresponding Author Email: fibi@pelitabangsa.ac.id

https://doi.org/10.18280/ijsse.100610

Received: 26 September 2020

Accepted: 5 December 2020

\section{Keywords:}

occupational health and safety, hazardous actions, hazardous condition, OSHA, frequency ratio, severity ratio

\begin{abstract}
Occupational health and safety is one of the most important issues in a company which is an important subject that has attracted a lot of attention in recent years. Work safety management system is the effort shown to the elements in production (human, equipment, materials and work environment), so that peaceful production activities can be realized and produce products that do not endanger the safety and health of workers. This is due to the interaction of elements in the production system in the form of death, serious injury, human injury, property damage and cessation of process loss. Primary data collection is done by distributing questionnaires to employees to record hazardous actions and hazardous conditions that are the direct cause of accidents resulting in serious injury and property damage or endangering workers and employees. The overall value of hazardous actions is $37 \%$ and hazardous conditions $24 \%$ still have a small effect that triggers the occurrence. OSHA measurement values prove that accidents, loss of time and other losses can be analyzed with the results of FR and SR values.
\end{abstract}

\section{INTRODUCTION}

Occupational health and safety is one of the most important issues in a company which is an important subject that has attracted a lot of attention in recent years. OHSAS 18001: 2007 is a worldwide standard of structural approach in occupational health and safety management systems and companies wishing to have occupational health and safety management systems in accordance with these standards can be formally certified by agencies certification [1]. The total cost of a work accident consists of the costs incurred to prevent a work accident and all types of costs that occur after a work accident and the losses caused by the accident. The strength and success of each company lies in the effective management of productivity, quality, safety, health and environment, including marketing and finance [2]. In recent years, occupational safety and health management has managed issues such as quality, environment, and human resources that are a major concern of the company [3]. The International Labor Office (ILO) classifies occupational accidents as follows: (a) the number of victims (accidents resulting in death or non-fatal injury resulting in inability to work for at least 3 consecutive days, excluding accident day); (b) the number of days lost, including the first 3 days, due to non-fatal injuries. Measuring safety performance that includes safety management, safety measures, accident statistics, accident investigations, and safety training practices is part of the overall performance of the organization [4]. Job satisfaction reflects the perception of an employee safety environment and organizational priorities [5]. Optimal productivity can be achieved through job satisfaction generated through the participation of occupational safety and health practices by providing occupational safety training [6]. Occupational
Accident Analysis occurs from the results of an accident assessment or a combination of accidents performed to find the main cause of the accident so that corrective conditions can be given so that similar accidents do not recur, as well as determine the legal subject responsible for the accident. The work safety management system is the effort shown to the elements in production (human, equipment, materials and work environment), so that safe production activities can be realized and produce products that do not endanger the safety and health of workers and avoid damage. Environment caused by factory waste or as a control loss from the risk of accidents that may arise due to the interaction of elements in the production system in the form of death, serious injury, human injury, property damage and cessation of process loss activities. That the need to provide a safe and healthy workplace can increase employee productivity and performance and produce a stronger balance sheet [7]. That one of the reasons for improving employee performance of a company is the increased relationship between these concepts of employee health and productivity in the workplace [8]. Safety in the workplace can eliminate many adverse effects (e.g., rising economic costs or unproductive employment due to increased savings, absenteeism and turnover due to outdated employees in terms of health and social relationships) [9].

\section{LITERATURE REVIEW}

To be increased employee satisfaction means improved production quality, productivity, profitability, competition, employee quality, and quality of life [10]. When employee satisfaction is low, health problems are rampant, which brings a serious cost burden to the company as well as the 
government [11]. Employee satisfaction is mostly focused on the significant impact on organizational performance [9]. Occupational safety contains several studies that discuss the impact of the implementation of safety management systems related to employee satisfaction in occupational accidents and diseases [12]. Employee satisfaction has a positive impact on company competitiveness [13]. Safety measures has a positive effect on employee satisfaction [14]. A strong relationship between the application of work safety management system and job satisfaction [15]. Work safety and poor working conditions cause stress resulting in certain organizational outcomes such as increased employee attendance, increased employee turnover, decreased performance, decreased productivity and quality, and increased grievances and anxiety among employees [16]. Employees have higher satisfaction and participate more in occupational health and safety activities when improvements are implemented [17]. A healthy and effective workplace can predict emotional commitment, emotional exhaustion, and employee well-being, which reflects employee satisfaction [18]. Grant et al emphasizes that on a network approach to security management systems to improve the welfare of employees and organizations. The level of its influence on employee performance, attendance ratio, behavioral disorders towards the company and employee health [9]. A clear negative relationship between accident rates and employee emotional and cognitive levels oriented to employee safety [10]. Factors based on the severity of the accident are an effective indicator for accident management resulting in employee injury, but these factors are not effective in controlling risk to major hazards [19]. A work safety assessment approach to enable organizations to make economic judgments [20]. The relationship between employee satisfaction and safety performance can be done by two methods, namely; Safety performance has a positive effect on employee satisfaction [21]. Several other researchers, that employee satisfaction has a positive effect on work accidents [22-24].

\section{METHODOLOGY}

Research data sources were collected from one of the automotive component industries in Jakarta from May 2019 to June 2020 at painting process. The method of collecting research data is qualitative research through research questionnaires to determine the results of hazardous actions and hazardous conditions in enterprises. The data collection process consists of two data, namely zero accidents and property damage data from May 2019 to June 2020. Primary data collection is done by distributing questionnaires to employees to record hazardous actions and hazardous conditions that are the direct cause of accidents resulting in injuries. weight and Damage to property or nearby injuries suffered by the employee or seen by the employee. The sampling method used is a non-probabilistic method in which the sample unit is selected based on the organizational strata and in each organizational strata a specific division is selected to represent the strata, namely the level of supervisor, employee, maintenance and job security.

\section{RESULT AND ANALYSIS}

The results of the investigation conducted in the period May 2019 to June 2020 are as follows (Table 1):

Table 1. Frequency of respondents

\begin{tabular}{|c|c|c|c|c|c|}
\hline NO & VARIABLE & FACTOR & PROBLEM & CATEGORY & SCALE \\
\hline \multirow[t]{10}{*}{1} & \multirow[t]{10}{*}{$\begin{array}{l}\text { HAZARDOUS } \\
\text { ACTIONS }\end{array}$} & Man & $\begin{array}{l}\text { Running machines / equipment without notice to } \\
\text { related parties. }\end{array}$ & $\begin{array}{l}\text { Often, Sometimes, } \\
\text { Never }\end{array}$ & Ordinal \\
\hline & & Method & $\begin{array}{l}\text { Running the machine / equipment is not in accordance } \\
\text { with the procedure (SOP). }\end{array}$ & $\begin{array}{l}\text { Often, Sometimes, } \\
\text { Never }\end{array}$ & Ordinal \\
\hline & & Method & $\begin{array}{l}\text { Shutting down machine / equipment without taking } \\
\text { security measures. }\end{array}$ & $\begin{array}{l}\text { Often, Sometimes, } \\
\text { Never }\end{array}$ & Ordinal \\
\hline & & Method & Repair the equipment in a safe condition. & $\begin{array}{l}\text { Often, Sometimes, } \\
\text { Never }\end{array}$ & Ordinal \\
\hline & & Method & $\begin{array}{c}\text { Observe the machine / equipment that is being } \\
\text { operated. }\end{array}$ & $\begin{array}{c}\text { Often, Sometimes, } \\
\text { Never }\end{array}$ & Ordinal \\
\hline & & Tools & Using safety equipment. & $\begin{array}{l}\text { Often, Sometimes, } \\
\text { Never }\end{array}$ & Ordinal \\
\hline & & Method & Placing work tools / equipment in a safe condition. & $\begin{array}{l}\text { Often, Sometimes, } \\
\text { Never }\end{array}$ & Ordinal \\
\hline & & Man & Joking around at work. & $\begin{array}{c}\text { Often, Sometimes, } \\
\text { Never }\end{array}$ & Ordinal \\
\hline & & Method & Make changes to the machine / equipment. & $\begin{array}{l}\text { Often, Sometimes, } \\
\text { Never }\end{array}$ & Ordinal \\
\hline & & Method & $\begin{array}{l}\text { Using a mixture of paint ingredients that are not } \\
\text { according to standards. }\end{array}$ & $\begin{array}{l}\text { Often, Sometimes, } \\
\text { Never }\end{array}$ & Ordinal \\
\hline \multirow[t]{8}{*}{2} & \multirow{8}{*}{$\begin{array}{l}\text { HAZARDOUS } \\
\text { CONDITIONS }\end{array}$} & Machine & Equipment for hazard alarms on process equipment. & Yes, No & Nominal \\
\hline & & Machine & $\begin{array}{l}\text { The place or equipment neatly arranged when it will } \\
\text { be used. }\end{array}$ & Yes, No & Nominal \\
\hline & & Method & Safety equipment is convenient to use. & Yes, No & Nominal \\
\hline & & Environment & Comfortable work environment. & Yes, No & Nominal \\
\hline & & Method & Availability of correct operating procedures. & Yes, No & Nominal \\
\hline & & Method & The availability of procedures for making changes. & Yes, No & Nominal \\
\hline & & Tools & Add tools to reduce noise and saturation. & Yes, No & Nominal \\
\hline & & Method & Gloves and masks are always available. & Yes, No & Nominal \\
\hline
\end{tabular}




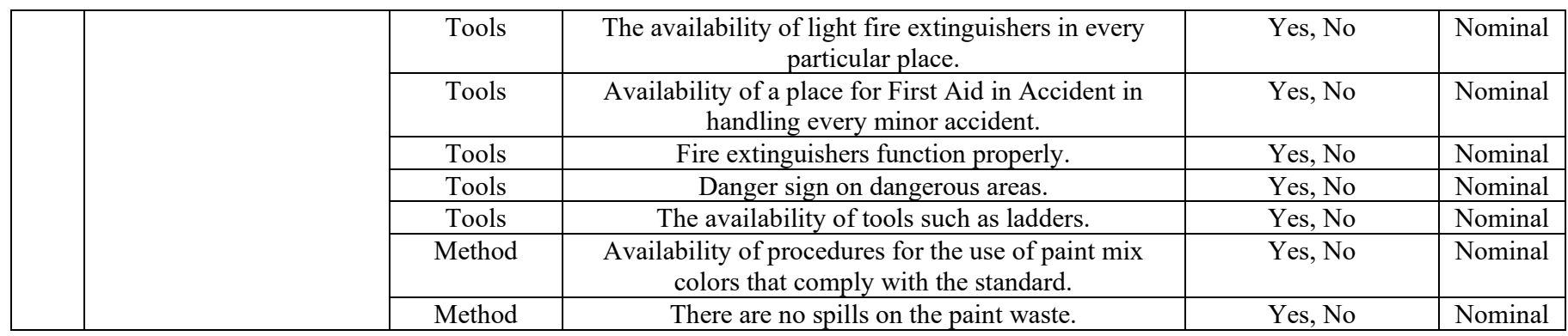

Until with a total of 30 respondents selected to represent the part of each strata, the results of data collection were done using questionnaires and interviews. The results of the company's damage property data resulted in a loss process that occurred between July 2019 to June 2020, which occurred in May 2020 where there was an employee who suffered physical fatigue and unconscious resulting in loss of 1 hour, but no material and machine damage.

From the total number of questionnaires distributed, the complete results of hazardous actions are as shown in the Table 2 below:

Table 2. Frequency distribution of hazardous actions

\begin{tabular}{|c|c|c|c|c|c|}
\hline \multirow{2}{*}{ NO } & \multirow{2}{*}{ FACTOR } & \multirow{2}{*}{ PROBLEM } & \multicolumn{3}{|c|}{ SCALE } \\
\hline & & & OFTEN & SOMETIMES & NEVER \\
\hline 1 & Man & Running machines/equipment without notification to the relevant parties. & 1 & 4 & 25 \\
\hline 2 & Method & $\begin{array}{l}\text { Running machines/equipment does not follow the procedure (Work } \\
\text { Instruction). }\end{array}$ & 0 & 5 & 25 \\
\hline 3 & Method & Turn off machines/equipment without performing security. & 3 & 2 & 25 \\
\hline 4 & Method & Fix the equipment in a safe condition. & 12 & 15 & 3 \\
\hline 5 & Method & Observe the machine/equipment in operation. & 24 & 3 & 3 \\
\hline 6 & Tools & Using security tools. & 2 & 10 & 18 \\
\hline 7 & Method & Laying tools/equipment work. & 3 & 3 & 24 \\
\hline 8 & Man & Joking in the work area. & 7 & 4 & 19 \\
\hline 9 & Method & Make changes in the work area. & 2 & 7 & 21 \\
\hline 10 & Method & Using non-standard paint mixing materials. & 1 & 3 & 26 \\
\hline & & TOTAL & 55 & 56 & 189 \\
\hline & & (PERCENTAGE) & $18,33 \%$ & $18,67 \%$ & $63,00 \%$ \\
\hline
\end{tabular}

Table 3. Frequency distribution of hazardous condition

\begin{tabular}{|c|c|c|c|c|}
\hline \multirow{2}{*}{ NO } & \multirow{2}{*}{ FACTOR } & \multirow{2}{*}{ PROBLEM } & \multicolumn{2}{|c|}{ SCALE } \\
\cline { 3 - 5 } & & YES & NO \\
\hline 1 & Machine & Instrument equipment against danger signs on process equipment. & 21 & 9 \\
\hline 2 & Machine & The place or equipment is well arranged when to use. & 26 & 4 \\
\hline 3 & Method & Comfortable work safety equipment to wear. & 22 & 8 \\
\hline 4 & Environment & Comfortable work environment. & 18 & 12 \\
\hline 5 & Method & Availability of proper operating methods/procedures. & 27 & 3 \\
\hline 6 & Method & Procedures for making changes have been made. & 21 & 9 \\
\hline 7 & Tools & Use a damper in the ear to reduce noise and saturation. & 22 & 8 \\
\hline 8 & Method & Gloves and masks are always there. & 26 & 4 \\
\hline 9 & Tools & Availability of light fire extinguishers in the work area. & 25 & 5 \\
\hline 10 & Tools & Availability of first aid kits to deal with minor accidents. & 27 & 3 \\
\hline 11 & Tools & The use of fire extinguishers works well. & 26 & 4 \\
\hline 12 & Tools & Signs of danger in dangerous areas. & 25 & 5 \\
\hline 13 & Tools & Availability of tools such as stairs. & 24 & 6 \\
\hline 14 & Method & Availability of correct work instructions/according to paint mix. & 24 & 6 \\
\hline 15 & Method & There has never been a spill of paint residue. & 8 & 22 \\
\hline \multicolumn{2}{r}{} & TOTAL & $\mathbf{3 4 2}$ & $\mathbf{1 0 8}$ \\
\hline \multicolumn{2}{r}{ (PERCENTAGE) } & $\mathbf{7 6 . 0 0 \%}$ & $\mathbf{2 4 . 0 0 \%}$ \\
\hline
\end{tabular}

From the total number of questionnaires distributed, the complete results for hazardous conditions are as shown in the Table 3.

The number of employees is 100 people with a total working time of 50 weeks a year. Meanwhile, the working hours of employees are 40 hours a week with a total of 1 accident ( 1 minor accident in 1 period). Meanwhile, the overtime regulation stipulated by Decree of the Minister of Manpower and Transmigration Number 102/2004 in Article 3 states that overtime work can only be done for a maximum of 3 hours in 1 day and 14 hours in 1 week. This means that the total overtime work for 1 year is 700 hours and 1 hour lost from the accident.

$$
S R=\frac{\text { number of lost working days } \times 1.000 .000}{\text { total working hours }}
$$




$$
\begin{gathered}
S R=\frac{1 \times 1.000 .000}{20700}=4.98 \\
F R=\frac{\text { total accident } \times 1.000 .000}{\text { total working hours }} \\
F R=\frac{0.1 \times 1.000 .000}{200700}=0.498
\end{gathered}
$$

Based on this calculation, the Severity Ratio value is 4.98 of the total accidents that occurred during that period and the Frequency Ratio value is 0.498 of the total working hours lost during that period. Meanwhile, the number of days lost is 0.1 (1 hour divided by 1 working day).

Furthermore, from the study data obtained by 30 respondents from 30 questions that answered hazardous actions and hazardous conditions are:

- Hazardous Actions which answered: Often (18.33\%), Sometimes (18.67\%) and Never (63\%).

- Hazardous Conditions which answered: Yes (76\%) and No $(24 \%)$.

Meanwhile, from the calculation of BLS-OSHA measurement, FR is 0.498 of the total number of work accidents per day in 1 year. While the SR value is 4.98 of the total time lost per day of labor in 1 year.

In proving Bird's Theory, it is found that the ratio of human accidents and property damage from the Damage Property Schedule is a minor accident (1), a waste of time (1 hour). While there is no zero number for serious accidents, there is still the possibility of increasing the potential for accidents. Meanwhile, the results of the questionnaire research data on the distribution of dangerous actions and the distribution of dangerous conditions proved to have calculated the Frequency (FR) of 0.498 accidents per day in a year and Severity Rate (SR) 4.98 many times lost every day in a year.

\section{CONCLUSION}

The conclusion that can be drawn from this study is as follows that based on the value from the results of the collection of questionnaires, the total value of hazardous actions is $37 \%$ and hazardous conditions $24 \%$ still have a small effect that triggers the incident. The OSHA value in painting process has a total FR value of 0.498 total daily work accidents in 1 year and in SR with a value of 4.98 total time lost per/day labor in 1 year. OSHA measurement values prove that accidents, loss of time and other losses can be analyzed with the results of FR and SR values. Assessment of Bird theoretical measurements are overall weight of hazardous actions, i.e. often (18.33\%), sometimes $(18.67 \%)$ and never $(63 \%)$, while for total weight of hazardous conditions, i.e. Yes $(76 \%)$ ) and No (24\%). The result of the ratio of human accidents and property damage from the property damage schedule is a minor accident (1), lost time wasted (1 Hour). The results of research data on the distribution of hazardous actions and the distribution of hazardous conditions have been shown to calculate the Frequency Rate (FR) of 0.498 accidents per day in a year and Severity Rate (SR) of 0.498 many times disappears every day of the year.

\section{REFERENCES}

[1] British Standards Institution (BSI), Occupational health and safety management systems - requirements, London: British Standards Institution (BSI), 2007.

[2] Venkataraman, N. (2008). Safety performance factor. International Journal of Occupational Safety and Ergonomics, 14(3): 327-331. https://doi.org/10.1080/10803548.2008.11076772

[3] Boyar, S.L., Campbell, N.S., Mosley Jr, D.C., Carson, C.M. (2014). Development of a work/family social support measure. Journal of Managerial Psychology, 29(7): 901-920. https://doi.org/10.1108/JMP-06-20120189

[4] Wu, T.C., Chen, C.H., Li, C.C. (2008). A correlation among safety leadership, safety climate, and safety performance. Journal of Loss Prevention in the Process Industries, $\quad$ 21(3): 307-318. https://doi.org/10.1016/j.jlp.2007.11.001

[5] Stoilkovska, B.B., Pančovska, V.Z., Mijoski, G. (2015). Relationship of safety climate perceptions and job satisfaction among employees in the construction industry: The moderating role of age. International Journal of Occupational Safety and Ergonomics, 21(4): 440-447. https://doi.org/10.1080/10803548.2015.1096059

[6] Al Idrus, S., Ahmar, A.S., Abdussakir. (2018). The effect of organizational learning on market orientation moderated by job satisfaction. Cogent Business \& Management, 5(1): 1-12. https://doi.org/10.1080/23311975.2018.1475048

[7] Falkner, L., Schneider, J., Arnold, J. (2012). Health and safety, prevention and accident costs in construction industry in international comparison/Arbeitsschutz, Prävention und Unfallfolgekosten im Bauwesen im internationalen Vergleich. Geomechanic and Tunnelling, 5(5): 621-630. https://doi.org/10.1002/geot.201200049

[8] Podgórski, D. (2000). Occupational health and safety management in Polish enterprises implementing total quality management systems. International Journal of Occupational Safety and Ergonomics, 6(sup1): 85-101. https://doi.org/10.1080/10803548.2000.11105110

[9] Öger, C.B. (2009). Insan kaynaklarında çalı,san memnuniyeti ve bir örnek olay [Employee satisfaction in human resource management: a case study]. Istanbul, Turkish: Y1ldız Technical University.

[10] Wachter, J.K., Yorio, P.L. (2014). A system of safety management practices and worker engagement for reducing and preventing accidents: An empirical and theoretical investigation. Accident Analysis and Prevention, 68: 117-130. https://doi.org/10.1016/j.aap.2013.07.029

[11] Aytaç, S. (2011). I,syeri kazalarını önlemede güvenlik kültürünün önemi [The importance of safety culture to prevent workplace accidents]. Turkish: Türkmetal Dergisi.

[12] Huang, Y.T., Rundle-Thiele, S. (2014). The moderating effect of cultural congruence on the internal marketing practice and employee satisfaction relationship: An empirical examination of Australian and Taiwanese born tourism employees. Tourism Management, 42: 196-206. https://doi.org/10.1016/j.tourman.2013.12.005

[13] Yorio, P.L., Wachter, J.K. (2014). The impact of human performance focused safety and health management 
practices on injury and illness rates: do size and industry matter? Safety Science, 62: 157-167. https://doi.org/10.1016/j.ssci.2013.08.014

[14] Gupta, A., Upadhyay, D. (2012). Impact of occupational health safety on employee satisfaction. International Journal of Science and Research, I(VII): 118-120.

[15] Omusulah, I.D. (2013). Percieved influence of occupational health and safety practices on job satisfaction among employees in Chemelil Sugar Company Limited, Nairobi. The University Of Nairobi

[16] Nahavandi, A., Malekzadeh, A.R. (1998). Organizational behavior. Upper Saddle River (NJ): Prentice-Hall.

[17] Torp, S., Moen, B.E. (2006). The effects of occupational health and safety management on work environment and health: A prospective study. Applied Ergonomics, 37(6): 775-783. https://doi.org/10.1016/j.apergo.2005.11.005

[18] Grawitch, M.J., Trares, S., Kohler, J.M. (2007). Healthy workplace practices and employee outcomes. International Journal of Stress Management, 14(3): 275293. https://doi.org/10.1037/1072-5245.14.3.275

[19] Arezes, P.M., Miguel, S.A. (2003). The role of safety culture in safety performance measurement. Measuring Business $\quad$ Excellence, 7(4): 20-28. https://doi.org/10.1108/13683040310509287

[20] Fitzgerald, M.K. (2005). Safety performance improvement through culture change. Process Safety and Environmental Protection, 83(4): 324-330. https://doi.org/10.1205/psep.04381

[21] Fernández-Muñiz, B., Montes-Peón, J.M., VázquezOrdás, C.J. (2012). Safety climate in OHSAS 18001certified organisations: Antecedents and consequences of safety behaviour. Accident Analysis and Prevention, 45: 745-758. https://doi.org/10.1016/j.aap.2011.10.002

[22] Gyekye, S.A. (2005). Workers' perceptions of workplace safety and job satisfaction. International Journal of Occupational Safety and Ergonomics, 11(3): 291-302. https://doi.org/10.1080/10803548.2005.11076650

[23] Gyekye, S.A., Salminen, S. (2006). Making sense of industrial accidents: the role of job satisfaction. Journal of Social Sciences, pp. 127-134. https://doi.org/10.3844/jssp.2006.127.134

[24] Rundmo, T. (1994). Associations between safety and contingency measures and occupational accidents on offshore petroleum platforms. Scandinavian Journal of Work, Environment \& Health, 20(2): 128-131. https://doi.org/10.5271/sjweh.1421 